\title{
A Study of Microfinance and Its Impact on the Livelihoods of Market Women; Evidence from Yilo Krobo Municipality, Ghana
}

\author{
Frederick Affum, (ICA, MBA) \\ Alumnus, Institute of Chartered Accountants, Ghana \& Kwame Nkrumah \\ University of Science and Technology, Ghana
}

Doi:10.19044/esj.2020.v16n16p216 URL:http://dx.doi.org/10.19044/esj.2020.v16n16p216

\begin{abstract}
The study examined the impacts of microfinance on the livelihoods of market women in the Yilo Krobo Municipality in the eastern region of Ghana. The mixed method approach was adopted thus using both qualitative and quantitative methods of collecting data. Questionnaires were distributed to market women selected conveniently whiles some purposively selected staffs and management of microfinance institutions (MFIs) were interviewed. The study revealed a positive impact of microfinance on the livelihoods of market women and their households. It was recommended that Microfinance Institutions should intensify the awareness of their services and maximize their training and education services for market women in the municipality to optimize the benefits derived by these market women in a way of subscribing to their services.
\end{abstract}

Keywords: Microfinance, Microfinance Institutions, Livelihoods, Market women, Ghana

\section{Introduction}

Microfinance has proved to be an integral part of the collective efforts contributing significantly to achieving the United Nations Millennium Development Goals according to the International Year of Microcredit (2005). The Millennium Development Goals (MDGs) which refers to eight international goals for the year 2015 were established following the Millennium Summit of the United Nations in the year 2000. These goals were aimed at eradicating extreme poverty and hunger, achieving a universal primary education, promoting gender quality and empowering women, reducing child mortality, improving maternal health, combating HIV/AIDS, malaria and other diseases, ensuring environmental sustainability and developing a global partnership for development, (United Nations 
Development Program, 2019). Microfinance schemes over the years have been one of the lead strategies adopted to eradicate poverty (MDGs 1), through the provision of financial support in the form of savings and credit opportunities to the poor or less privileged, (Johnson \& Rogaly, 1997).This have been verified to result in poverty alleviation through income generation, jobs creation, allowing children to go to school, enabling families to obtain health care, and empowering people to make the choices that best serve their needs (Asamoah, 2006). The variety of financial services of microfinance operations are targeted at low-income clients, particularly market women, (Microfinance Information Exchange, 2011), who are normally excluded from traditional financial systems due to lack of collateral, steady employment and a verifiable credit (Egyir, 2010). These vulnerable women are abetted not only with small loans to help them engage in productive activities or grow their small businesses, but over time, provides them with a broader array of services such as credit, savings, insurance, money transfer facilities. This is because microfinance developers have come to realize that the poor who lack access to traditional formal financial institutions require a variety of financial products to help them grow their businesses, support their households and to engender sustainable livelihoods of which market women are not excluded (Hagen, 2004).

Contrary to the assertions above, there still exists a lingering doubt about microfinance impacts on society and the livelihoods of its subscribers as some scholars have stressed that microfinance schemes have been less effective and therefore failed to reduce poverty as it was intended to. For instance, (Otoo, 2012) argued that, microfinance is not a panacea for poverty alleviation because in some cases the poorest people have been made worseoff. Microfinance support cannot be the end against poverty and rural enterprise sustenance in Ghana and other developing countries, but rather a means to assist the needy especially market women (Otoo, 2012). Asiamah and Osei (2007) also mentioned that, there has been an over-estimation of the impact of microfinance operations in bettering the livelihoods of people especially the poor. It is against this background, this study have been conducted to ascertain the impact of microfinance activities on the livelihoods of market women in the Yilo-Krobo Municipality with the intention to finding an answer to whether market women are benefiting from microfinance services or operations or not.

\section{Research Aim \& Objectives}

The aim of the study is to ascertain the impact of microfinance operations on the livelihoods of market women in the Yilo-Krobo Municipality. The specific objectives covered the following variables; 
- To assess the impact of the microfinance operations on the livelihood of market women in Yilo-Krobo Municipality

- To identify how market women in the Yilo-Krobo Municipality utilizes loans obtained from microfinance institutions

\section{Literature Review}

Diverse definitions exist when the topic of microfinance is raised. For instance, according to Dzisi and Obeng (2013) "microfinance encompasses the provision of financial services and the management of small amounts of money through a range of products and a system of intermediary functions that are targeted at low income clients especially petty trader's and market women in the society". Ike (2012) also described microfinance as services referring to loans, deposits, insurance, fund transfer services and other ancillary financial assistance given to the poor in society". Non-financial products, such as training and development of social capital targeted at low income clients also constitute this scope. Basically, the three features distinguishing microfinance from other formal financial products are namely: smallness of loans and savings, absence or reduced emphasis on collateral security, and, simplicity of operations (Ike, 2012). Frimpong and Nguerenomo (2014) posited that microfinance encompasses the provision of financial services and a range of products with a system of intermediary functions that are targeted at low income clients. It basically, includes loans, savings, insurance, transfer services and other financial products and services. From the definitions above, one can deduce that, the fundamental mandate of microfinance is the provision of financial services and other supporting managerial functions to low income earners, or the poor in the society who are mostly excluded from the mainstream banking services.

Microfinance operates through Institutions. It is, therefore, prudent that microfinance institutions are also defined. According to Ablorh (2011), microfinance institutions (MFIs) consist of agents and organizations that are engaged in relatively small financial transactions using specialized, characterbased methodologies to serve low-income households, micro enterprises, small farmers, and others who lack access to the banking system. Microfinance covers a broad variety of institutional arrangements and approaches. They range from small self-help groups with a handful of members to huge organizations that have nationwide coverage and millions of clients. MFIs can be non-governmental organizations (NGOs), Savings and Loans Companies, Credit Unions, Government Banks, Commercial Banks, or Non-Bank Financial Institutions (Ablorh, 2011). Through these Institutions social intermediation services such as group formation, development of selfconfidence, and training in financial literacy and management capabilities 
among members of a group are provided to their subscribers or customers in addition to the financial services.

\section{Components of Microfinance}

Microcredit: Microfinance and microcredit are used interchangeably but it is very essential to highlight the difference between them. Microcredit refers to the constituent of microfinance which involves providing credit to the poor. The difference between microfinance and microcredit is the provision of non-financial such as savings, insurance, pension and payment services as undertaken with regards to micro financing, whereas microcredit only involves the provision of credit (Okiocredit, 2005).

Micro savings: Micro savings is a branch of microfinance, consisting of a small deposit account offered to lower-income families or individuals as an incentive to store funds for future use. Micro savings accounts work similar to a normal savings account, however, are designed around smaller amounts of money. The minimum balance requirements are often waived or very low, allowing users to save small amounts of money and not be charged for the service (Kagan, 2018). This program is to enable savings among beneficiaries of microfinance for future needs.

Micro Insurance: Micro insurance refers to the arrangement that offers protection to individuals and groups with low income against specific risk in exchange for premium payments. This follows the generally accepted insurance products even though they are designed specifically to meet those who are unable to have access to mainstream insurance. Studies have revealed that micro insurance has helped beneficiaries of microfinance in cushioning them against disaster or unforeseen unfavorable occurrences (Allen \& Overy, 2012).

\section{History of Microfinance in Ghana}

Indisputably, microfinance is not a new conception in Ghana. It has always been common practice for people to save and or take small loans from individuals and groups within the context of self-help in order to engage in small retail businesses or farming ventures. Unreliable evidence suggests that, the first credit union in Africa was probably established in Northern Ghana in 1955 by the Canadian Catholic missionaries that were there at the time. However, Susu, which is one of the current microfinance schemes in Ghana, is thought to have originated in Nigeria and spread to Ghana from the early 1900s. Over the years, the microfinance sector has bloomed and evolved into its current state, owing to the various financial sector policies and programs such as the provision of subsidized credits, establishment of rural and community banks (RCBs), the liberalization of the financial sector and the promulgation of PNDC Law 328 of 1991 that allowed the establishment of 
different types of non-bank financial institutions, including savings and loans companies, finance houses, and credit unions, (Bank of Ghana, 2007).

According to the Bank of Ghana (2007), there are three broad types of microfinance institutions operating in Ghana. These include:

- Formal suppliers of microfinance (i.e. Rural and community banks, savings and loans companies, commercial banks).

- Semi-formal suppliers of microfinance (i.e. credit unions, financial non-governmental organizations (FNGOs), and cooperatives,

- Informal suppliers of microfinance (e.g. Susu collectors and clubs, rotating and accumulating savings and credit associations (ROSCAs and ASCAs), traders, moneylenders and other individuals).

In terms of the regulatory framework, rural and community banks are regulated under the Banking Act 2004 (Act 673), while the Savings and Loans Companies are currently regulated under the Non-Bank Financial Institutions (NBFI) Law 1993 (PNDCL 328), (Asiamah and Osei, 2007).

\section{Impact of Micro-Finance on Market Women}

Innumerable studies have shown that microfinance indeed have positive effects on each of these different dimensions of women's empowerment. For example, a microfinance institution in the Philippines known as Tulaysa Pag-unlad, Inc. (TSPI) reported a dramatic increase, from 33 to 51 percent, in women's role as funds managers in their households, with only 5 per cent relinquishing control of household funds management during that period as cited by (Ledesma, 2002). Microfinance makes credit directly available to the very poor and thereby promotes their self-sufficiency. Institutions of microfinance have reached out to many disadvantaged micro entrepreneurs by assisting them to build operational and financial selfsufficiency. The rationale of microfinance was to bring at door step, banking services to rural and low-income segment of the society who cannot meet the requirement of orthodox commercial banks (Iheduru, 2002). Equally, Gobezie (2010) found out that, microfinance has come to play a major role in many gender and development strategies because of its direct association to both poverty alleviation and women empowerment. This has manifested in the light of giving women access to working capital and training. Microfinance helps to mobilize women's productive capacity to alleviate poverty and maximize economic output (Gobezie, 2010).

Additionally, investing in women has proven to increase the positive impact of microfinance programs since women are more likely than men to spend their income on household and family needs as supported by (Mersland, 2009). Records available by the World Bank (2007) stipulated that, microfinance activities are likely to increase women monetary income, their 
control over their income and their bargaining power. These effects are then expected to lead to various social, psychological and even political effects which are mutually reinforcing, better self-esteem and self-confidence, improvement in status within the family and the community, better spatial mobility and visibility of women in public spaces among others.

\section{Utilization of Loans credits}

Dzisi and Obeng (2013) writing on microfinance and the socioeconomic wellbeing of women entrepreneurs in Ghana brought to light that, the enterprises of many women have expanded after having access to loans from microfinance institutions, denoting, loans obtained by market women from microfinance institutions are used as capital for start of business or capital expansion. The research adopted a multi-method approach that is, the use of questionnaire and interviewing to collect the data and information for the study. In all 840 women benefiting from microfinance facilities were considered for the study. The study recommended that: the microfinance institutions should organize training for their clients. Dzisi and Obeng, comments that, microfinance in Ghana has always been a common practice for people to save and/or take small loans from individuals and groups within the context of self-help in order to engage in small retail businesses or farming ventures. Similarly, Asamoah (2006) also concluded that, micro-credit has positive implications on woman's economic empowerment. It helps them to increase and sustain their working capital, purchase more raw materials and goods for increased production, as well as expand their options and choices regarding where and whom to buy goods. It also helped them to save at the bank. This indirectly helped them to assimilate banking practices and subsequently made them eligible for bank loans. The International Labor (ILO) in Geneva, (1999) highlighted that, children of women microfinance borrowers also reap the benefits, as there is an increased likelihood of fulltime school enrolment and lower drop-out rates. Studies show that new incomes generated from microenterprises are often first invested in children's education, particularly benefiting girls. Households of microfinance clients appear to have better health practices and nutrition than other households. In contrast, some theorists and schools of thought, however, remain skeptical about the role of micro-credit in development. For example, while acknowledging the role micro-credit can play in helping to reduce poverty, Otoo (2010) concluded from their research that most contemporary schemes are less effective than they might be. The authors argue that micro-credit is not a panacea for poverty-alleviation and that in some cases the poorest people have been made worse-off. Notwithstanding these observations, microfinance has emerged globally as a leading and effective strategy for poverty reduction 
with the potential for far-reaching impact in transforming the lives of poor people.

\section{Research Methodology}

The research adopted the mixed method approach that is the use of, both qualitative and quantitative approach in collecting and analyzing data. The use of the approach was to blend and verify the information and data collected from the participants. The study targeted one hundred and twenty (120) market women and ten (10) core staffs from the selected microfinance institutions in the area under study in the Yilo Krobo Municipality in the Eastern Region of Ghana. The market women who participated in the study were selected at their own convenience while a non- probability sampling approach, was used to select the staffs of selected microfinance institutions. Questionnaires and an interview guides were used to collect the data and information from the market women and staffs of microfinance institutions. The study questionnaire involved close-ended and open- ended questions catching the objectives of the research work. The close-ended questions were used mainly to limit the category of response by given alternative responses. The open-ended questions were also adopted to enable respondents to be expressive in connection with the topic understudy. The questionnaire consisted of three (5) sections. Section A; the demographic characteristics of the market women, section B; impact of microfinance operations on the livelihoods of market women, Section C; utilization of the loans by the market women, Section D; evaluation of Impact of microfinance on the livelihoods of market women and Section E; Level of satisfaction among market women.

The researcher adopted the face-to- face and telephone method of interview. The face to-face strategy was used because the presence of the interviewer generally decreases the habit of excuse among participants. It also helps to clarify the intent of certain questions in the questionnaire and the results and views are recorded immediately after the interview. The interview schedule was used purposely to elicit information from the selected management and staffs from the microfinance institutions. Though initially it was difficult to book appointments to enable the researcher interview the staff, the interview was successfully conducted. The data used was both primary and secondary sources. The questionnaire and interview schedule were used to collect the primary data. Textbooks, journal articles, theories of motivation, reports, bulletins and related works on the topic were consulted for the secondary data. The researcher visited the market women on Monday and Thursdays which are the market days in the district and assisted the women to fill the questionnaire due to their busy schedule. It took a period of two (2) weeks to complete the process. The quantitative data was analyzed with the use of Statistical Package for Social Sciences (SPSS). Variables were coded 
in the variable view and the answered questionnaires, also entered in the data view to generate the required reports. Besides, qualitative content analysis was used to analyze the information obtained from interviewing the core staff of the microfinance. The results were organized reflecting the objectives of the research.

\section{Results and Discussion of Findings}

Out of 120 copies of questionnaires distributed to market women, 104 copies were retrieved fully completed representing 87\%. Although, the researcher went through many difficulties, the process was interesting especially interacting with the different categories of the market women.

\section{Demographic Characteristics of Respondents}

Table1: Demographic Data: Age of Respondents

\begin{tabular}{|c|r|r|}
\hline Age & \multicolumn{1}{|c|}{ Frequency } & Percentage \\
\hline $20-25$ & 15 & $14 \%$ \\
\hline $26-30$ & 25 & $24 \%$ \\
\hline $31-35$ & 15 & $14 \%$ \\
\hline $36-40$ & 39 & $38 \%$ \\
\hline $41-50$ & 10 & $10 \%$ \\
\hline Total & $\mathbf{1 0 4}$ & $\mathbf{1 0 0 \%}$ \\
\hline \multicolumn{2}{|c|}{ Source: Survey data, 2018 } \\
\hline
\end{tabular}

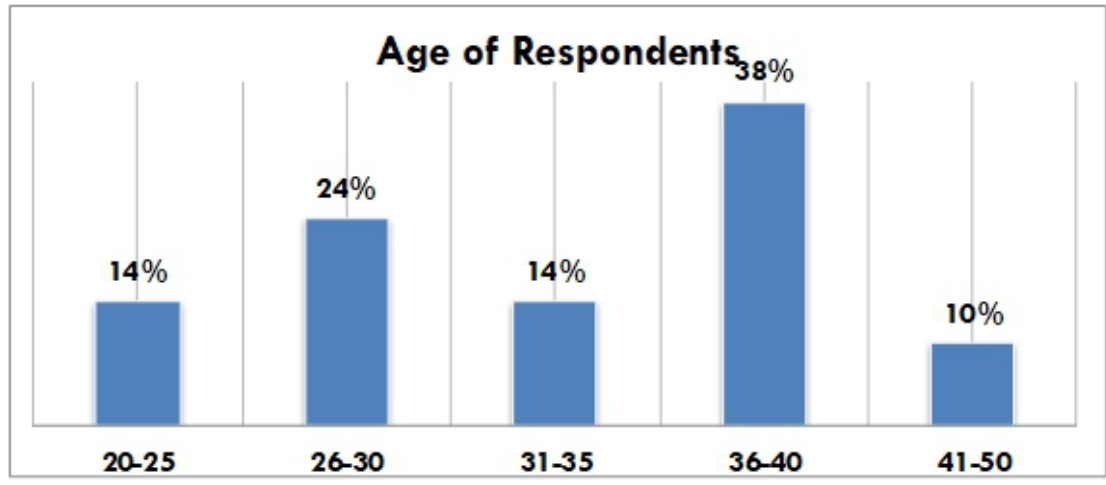

Figure 1: Survey data, 2018

With reference to the demographic characteristics of respondents in terms of age, the data collected indicated that, 15 respondents representing $14 \%$ were within 20-25 years age group, 25 respondents representing $24 \%$ were within 26-30 years age group, 15 respondents representing $14 \%$ also fell within 31-35 years age group, 39 respondents signifying 38\% within the group of 36-40 whiles 10 respondents $9.6 \%$ fell within the group of 41-50 years. The demographic data above showed that most of the respondents were between the ages of 36 to 40 years. 
Table 2: Demographic Data: Literacy Level of Respondents

\begin{tabular}{|l|r|r|}
\hline Education & Frequency & Percentage \\
\hline Illiterate & 10 & $10 \%$ \\
\hline Primary / JHS & 20 & $19 \%$ \\
\hline SHS/VOC & 70 & $67 \%$ \\
\hline Tertiary & 4 & $4 \%$ \\
\hline Total & $\mathbf{1 0 4}$ & $\mathbf{1 0 0 \%}$ \\
\hline
\end{tabular}

Source: Survey data, 2018

\section{Literacy Level of Respondents}

Elliterate = Primary/JHS = SHS/VOC Iertiary

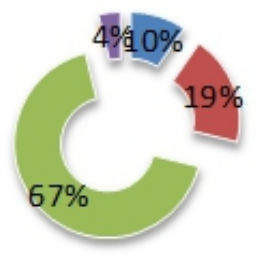

Figure 2: Survey data, 2018

Regarding educational level of the respondents, $10 \%$ were illiterates, $19 \%$ were Primary/JHS graduates, $67 \%$ were graduates of SHS/Vocational whiles $4 \%$ were tertiary graduates. This portrays that majority of respondents had SHS/Vocational background of education.

Table 3: Impact of Microfinance on Livelihood of Women

\begin{tabular}{|l|r|r|}
\hline Impact of Microfinance & Frequency & \multicolumn{1}{|c|}{ Percentage } \\
\hline $\begin{array}{l}\text { Better Standard of } \\
\text { Living }\end{array}$ & 50 & $48 \%$ \\
\hline Taking care of family & 30 & $29 \%$ \\
\hline Paying off debts & 10 & $10 \%$ \\
\hline $\begin{array}{l}\text { Reduce the habits of } \\
\text { unnecessary borrowing }\end{array}$ & 10 & $10 \%$ \\
\hline Others & 4 & $4 \%$ \\
\hline Total & $\mathbf{1 0 4}$ & $\mathbf{1 0 0 \%}$ \\
\hline
\end{tabular}

Source: Survey data, 2018 


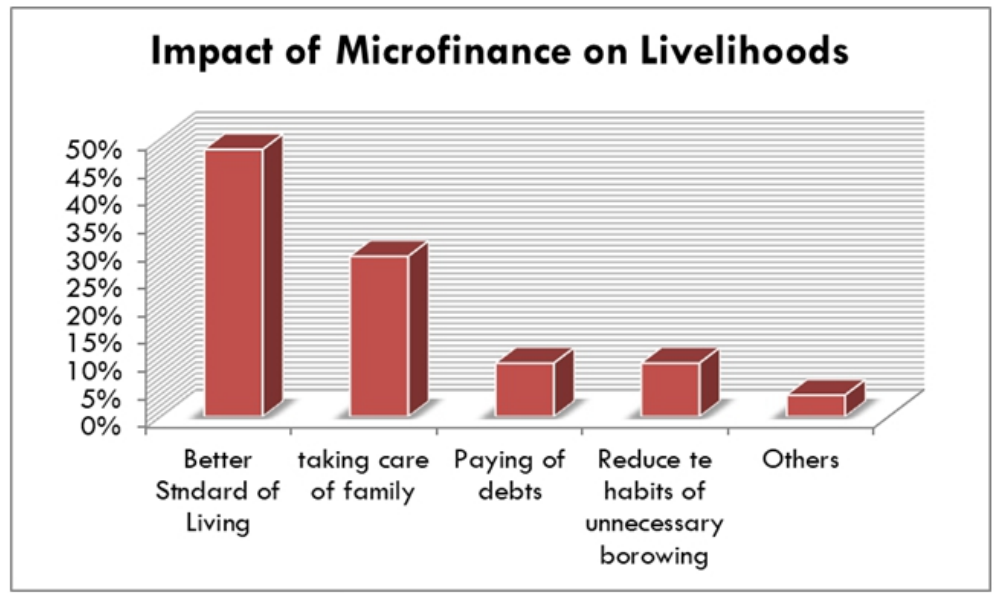

Figure 3: Survey data, 2018

Results from figure 3 indicates that, out of the total valid respondents of 104 on the impact of microfinance on livelihood, $48 . \%$ indicated that Microfinance has bettered their standard of living, 29\% indicated they are able to take care their of family matters, $10 \%$ of the respondents were of the view through microfinance, their habit of unnecessary borrowing has been drastically reduced, $10 \%$ were also of the view that it has helped in them to payment their outstanding debts, whereas $4 \%$ of the respondents stated that it had impact on other factors such as improved status in their respective communities, churches and countless others. It could be deduced that, from the responses that microfinance had impacted on the livelihoods of market women in the Yilo Krobo Municipality. From the interviews conducted, it was confirmed that microfinance has impacted their clients in terms of raising working capital which improves their business and standards of living. Management of the microfinance institutions revealed that most of the beneficiaries of the microfinance schemes rendered had personally visited their offices to testify its impact. Furthermore, there are teams from the serving body who also visit the market women to assess the impact. This confirms the findings of previous authors like Asamoah (2006), Dzisi and Obeng (2013), Hagan (2004) and Asiamah et al (2007) who agreed that microfinance activities support the livelihood of the beneficiaries.

Table 4: Impact of Microfinance on Livelihood of Women

\begin{tabular}{|l|r|r|}
\hline Utilization of Loan & \multicolumn{1}{|c|}{ Frequency } & Percentage \\
\hline Starting up a Business & 90 & $87 \%$ \\
\hline $\begin{array}{l}\text { Paying School Fees of } \\
\text { Children }\end{array}$ & 2 & $2 \%$ \\
\hline Paying Health Care & 10 & $10 \%$ \\
\hline Others & 2 & $2 \%$ \\
\hline Total & $\mathbf{1 0 4}$ & $\mathbf{1 0 0 \%}$ \\
\hline
\end{tabular}

Source: Survey data, 2018 


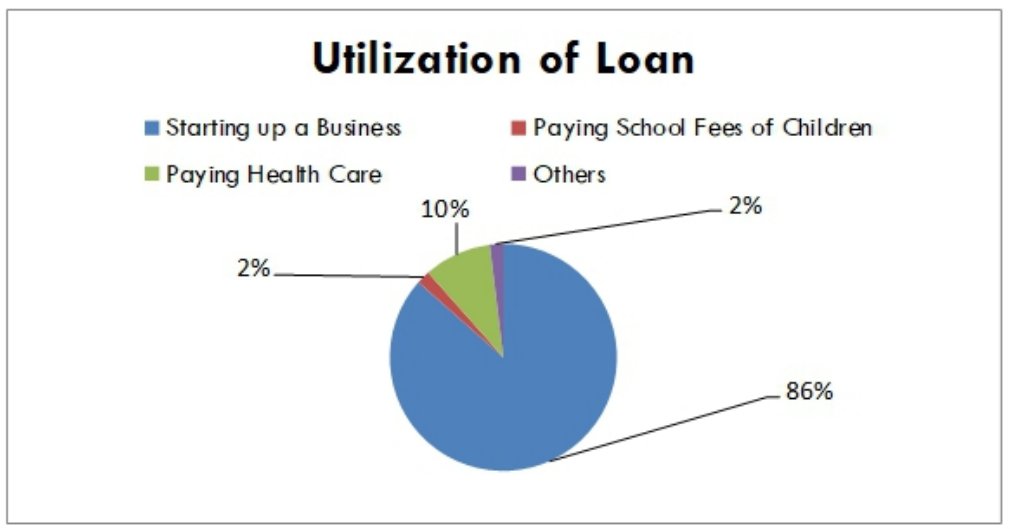

Figure 4: Survey data, 2018

Table 5: Evaluation of Microfinance Impact

\begin{tabular}{|l|r|r|}
\hline Evaluation of Impact & Frequency & Percentage \\
Excellent & 50 & $48 \%$ \\
\hline Good & 20 & $19 \%$ \\
\hline Fair & 25 & $24 \%$ \\
\hline Poor & 9 & $9 \%$ \\
\hline Total & $\mathbf{1 0 4}$ & $\mathbf{1 0 0 \%}$ \\
\hline
\end{tabular}

Source: Survey data, 2018

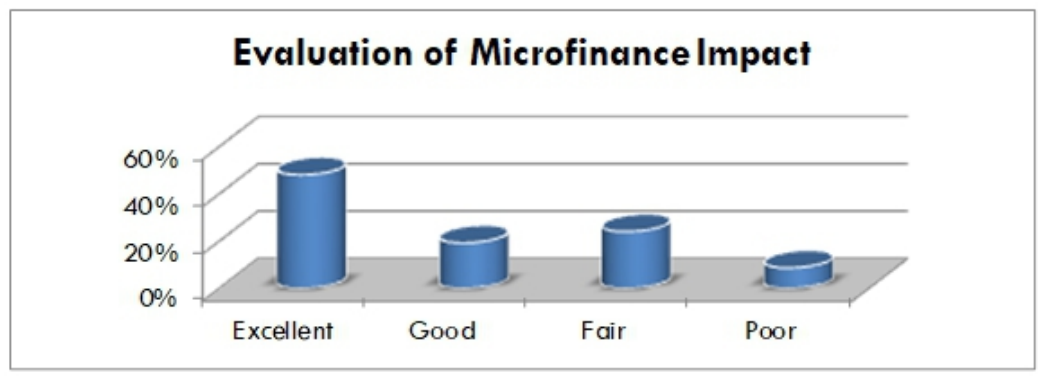

Figure 5: Survey data, 2018

Results from Table 4.5 indicates that out of the valid results of 104 respondents, in evaluating the impact of microfinance, $50(48 \%)$ indicated excellent, 20(19\%) indicated good, 25(24\%) indicated fair while 9(9\%) said poor. The views of the service providers during the interview was not different from those of the clients, they all held a common opinion on the issue of the evaluation of the impact. It could be concluded that the impact of microfinance activity had a considerable and visible impact on the respondents. This revelation is not different Obeng \& Dzisi (2013) as well as Asiamah et al (2007). 
Table 6: Level of Satisfaction

\begin{tabular}{|l|r|r|}
\hline Level of Satisfaction & Frequency & Percentage \\
\hline Very Satisfied & 40 & $38 \%$ \\
\hline Satisfied & 30 & $29 \%$ \\
\hline Not Very Satisfied & 25 & $24 \%$ \\
\hline Not Satisfied & 9 & $9 \%$ \\
\hline Total & $\mathbf{1 0 4}$ & $\mathbf{1 0 0 \%}$ \\
\hline
\end{tabular}

Source: Survey data, 2018

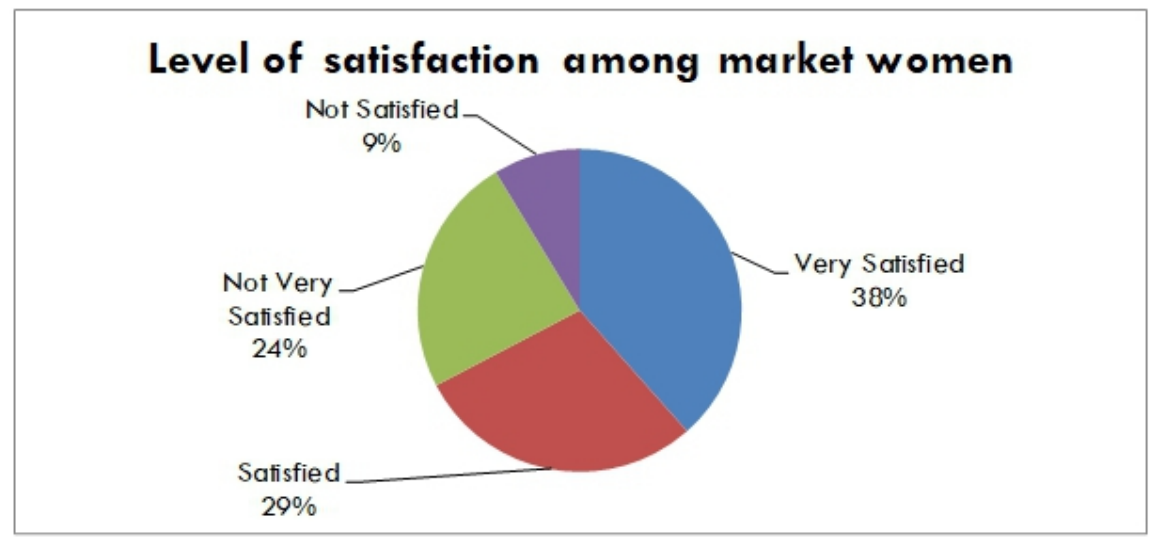

Figure 6: Survey data, 2018

Table 4.6 shows that, out of the valid response of 104, regarding level of satisfaction of the impact of microfinance activities, 40 respondents (38\%) were very satisfied with the impact of microfinance activities on the livelihood, 30 respondents (29\%) were satisfied, 25 respondents (24\%) were not very satisfied and 9 respondents $(9 \%)$ were not satisfied. This could be concluded that most of the respondents were satisfied with the activity of the microfinance as it has helped improved their standard of living and that of their families. The finding confirmed the argument of Dzisi et al (2013), who echoed that market women are always empowered through provision of credit facilities from microfinance.

\section{Conclusion and Recommendations}

The study confirmed that, the assistance given to market women through microfinance schemes has a substantial impact on their livelihoods. This was visible especially among the children and the aged people of the women's family. The research results showed that, most of the market women use the loans obtained from microfinance to do a lot of pressing issues such as paying of medical bills, school fees, but most of them used it to set up new business or expand existing ones. Moreover, a few of the respondents were also not satisfied due to long processes involved in obtaining credit facilities and sometimes collaterals been demanded by the microfinance institutions. 
These two issues present another research area that will be conducted in the future. Based on the findings of the study, the researcher will recommend that microfinance institutions should intensify their marketing drive in the municipality for the market women to create awareness of their products and services. It is also recommended that microfinance institutions in the municipality should intensify their education and training programs to the market women to sustain the good impacts microfinance is having on their livelihoods, and their various micro-enterprises. The market women should be given training in financial literacy and capital management to help them.

\section{References :}

1. Ablorh, W. (2011). Microfinance and socio-economic empowerment of women: A case of Opportunity International Savings and Loans clients. Kwame Nkrumah University of Science and Technology (Unpublished Master's Dissertation), 16-19. Available at http://dspace.knust.edu.gh:8080/jspui/bitstream/123456789/4196/1/A blorh\%20thesis.pdf

2. Allen \& Overy LLP (2012). "Micro insurance". Advocates for International Development. Archived from the original (PDF) on 20 December 2013. Retrieved 20 August 2013.

3. Asamoah, M. (2006). Empowering women economically through microcredit- prospect and challenges: the case of some selected credit schemes in the Eastern Region of Ghana

4. Asiama, J. P. And Osei, V. (2007). Microfinance in Ghana: An Overview. Accra, Ghana: Research Department, Bank of Ghana.

5. Dzisi S. \& Obeng, F. (2013). Microfinance and the Socio-economic Wellbeing of Women Entrepreneurs in Ghana, International Journal of Business and Social Research (IJBSR), Volume -3, No.-11, November, 2013 Economics 60, 229-248.

6. Egyir, I. S. (2010). "Rural Women and Microfinance in Ghana: Challenges and Prospects," Contributed Paper presented at the Joint 3rd African Association of Agricultural Economists (AAAE) and 48th Agricultural Economists Association of South Africa (AEASA) Conference, Cape Town, South Africa, September 19-23, 2010.

7. Frimpong S. K. \& Nguerenomo J. L. K. (2014). Assessing the Contribution of Microfinance Institutions to Poverty Reduction in Ghana: A Case Study of the Christian Rural Aid Network (CRAN) Hohoe, Ghana. Unpublished Thesis, S M U, Ghana.

8. Gobezie, G. (2010). Empowerment of Women in Rural Ethiopia: A Review of Two Microfinance Models. PRAXIS the Fletcher Journal of Human Security. Vol. XXV. 
9. International Labor Organization (ILO) (1999). Job Creation in Small and Medium-Sized Enterprises: Guide to ILO Recommendation No 189. Geneva: ILO.

10. International Year of Microcredit, (2005). Microfinance and the Millennium

DevelopmentGoals:https://www.yearofmicrocredit.org/docs/MF_MD Gs.pdf.

11. John P. Asiamah, Peter Osei, (2007). Microfinance in Ghana: An Overview. Economics Web Institute, http://economicswebinstitute.org/essays/microfinanceghana.htm.

12. Johnson, S. \& Rogaly, B. (1997). Microfinance and Poverty Reduction. London: ACTIONAID, OXFAM, UK.

13. Julia Kagan, (2018). Micro savings: https://www.investopedia.com/terms/m/microsavings.asp.

14. Ledesma, Jesila (2002). "Empowerment Impact Report on TSPI's Kabuhayan program."

15. Mersland, R. (2009). The Cost of Ownership in Microfinance Organizations. World Development, 37,469-478.

16. Microfinance Information Exchange, (2011). From http://www.mixmarket.org/ REFID: 7 MIX publications. (2011). Sacrificing unrealistic goals. Retrieved 08/05, 2011, from 19http://www.themix.org/publications/microbankingbulletin/2011/01/sacrificingmicrocredit unrealistic goals REF ID: 35 .

17. Ngozi G. Iheduru (2002). Women Entrepreneurship and Development: The Gendering of Microfinance in Nigeria.

18. Okiocredit (2005). Small Loans Great Change: building a future with Microfinance. In: International Microfinance Symposium, Bonn

19. Otoo, B.K. (2012). Micro-Credit for Micro-Enterprise: A Study of Women "Petty" Traders in Central Region, Ghana International Journal of Scientific Research in Education, SEPTEMBER 2012, Vol. 5(3), 247-259.

20. United Nations Development Program, (2019). Millennium Development

Goals:https://www.undp.org/content/undp/en/home/sdgoverview/md g goals.html.

21. World Bank (2007). Finance for All? Policies and Pitfalls in Expanding Access: A World Bank Policy Research Report, the World Bank: Washington. 